International Journal of Production Economics, 2008, Vol 111(1) pp27-41

\title{
THE DESIGN AND OPERATION OF DISTRIBUTION CENTRES WITHIN AGILE SUPPLY CHAINS
}

Peter Baker

Cranfield University

\begin{abstract}
Although the need to respond to volatile market places has been addressed in recent years by the concept of agility, the precise role of distribution centres within agile supply chains has only been partially explored. This paper examines this particular area by means of nine case studies into how individual business units design and operate distribution centres to provide a rapid response to their markets. The solutions used by these companies are categorised to form a framework for addressing this subject and as a basis for further research into the practical application of agility at the distribution centre level.
\end{abstract}




\section{Contact details:}

Peter Baker

Centre for Logistics and Supply Chain Management

Cranfield School of Management

Cranfield University

Bedford

MK43 OAL

United Kingdom

Tel: +441234751122

Fax: +44 1234752441

E-mail:peter.baker@cranfield.ac.uk 


\section{THE DESIGN AND OPERATION OF DISTRIBUTION CENTRES WITHIN AGILE SUPPLY CHAINS}

Keywords: Warehousing; Agility; Flexibility; Capability; Competency.

\section{Introduction}

With many markets becoming volatile and difficult to predict, the focus of supply chain management has needed to "shift from the idea of cost as an order winner to responsiveness as the market winner" (Christopher and Towill, 2002,p1). Cost, however, remains a market qualifier in such situations (Mason-Jones et al., 2000) and therefore agile supply chains are faced with the twin pressures of providing greater responsiveness whilst keeping costs at a low level.

In general, the minimisation of inventory is key to achieving these objectives, by means, for example, of substituting information for inventory (Christopher, 1998). Distribution centres thus need to assist the rapid flow of goods through the supply chain, using techniques such as transhipping between warehouse sites (Herer et al., 2002) or cross docking and intransit merging (van Hoek, 2001). Production postponement at the distribution centres may also be part of this agile strategy (Marvick and White, 1998), including such activities as final packaging, labelling and configuration to customer requirements (Maltz and DeHoratius, 2004).

However, national statistics indicate that inventory has remained at a constant level in recent years, in relation to changes in Gross Domestic Product, in the US and UK economies (Frazelle, 2002a; Office for National Statistics, 2005), whilst empirical research has indicated that the use of cross docking and postponement is somewhat limited (Baker, 2004). In fact, it 
is recognised that the holding of inventory may form part of an agile strategy as decoupling points may be useful to separate lean manufacturing practices (which are more effective in stable supply situations) from downstream agile supply chains that serve volatile market places (Naylor et al., 1999). This need for decoupling points is becoming increasingly important with global sourcing which tends to be associated with increased lead times.

The purpose of this paper is to explore how companies are in fact responding to the need for agility, particularly as regards how they design and operate their distribution centres to support their responsiveness to the market. Modern distribution centres are frequently very large in size as a result of the benefits of consolidating inventory and the long supply lines resulting from global sourcing (Harrison and van Hoek, 2005). These large distribution centres frequently contain significant levels of automated equipment in order to contain operating costs within such complex sites (Pfohl et al., 1992). With the warehouse buildings having approximately a 25 year depreciation period in companies' accounts and the equipment about a 5 to 10 year depreciation period, reconciling this long life of assets with supply chain agility is a significant issue.

\section{Context}

Agility is a business-wide concept that has its origins in manufacturing flexibility (Aitken et al., 2002). It may be described as a "management concept centered around responsiveness to dynamic and turbulent markets and customer demand" (Van Hoek et al., 2001, p146). Indeed, agility involves not only responding to changing market conditions but exploiting and taking advantage of these changes as opportunities (Sharifi and Zhang, 1999).

Whilst the concept therefore addresses particular types of markets (Childerhouse and Towill, 2000), the need for agility is becoming increasingly important as product life cycles 
shorten and global economic and competitive pressures lead to additional uncertainty (Christopher, 2000). In this environment, companies need to locate inventory and capacity at strategic points in the supply chain to facilitate the flow of goods to market (Stratton and Warburton, 2003).

In order to provide this responsiveness, firms require flexible capabilities across a number of areas, such as product development, manufacturing and logistics. Within each area, specific competencies are required to provide these capabilities (Zhang et al., 2002). A wellknown example of a competence at distribution centre level was documented by Stalk et al., (1992), namely Wal-Mart's cross-docking logistics operation, which enabled goods to be "pulled" by consumer sales data directly from suppliers. In fact, the whole logistics operation can be viewed as a resource base within a firm to support new strategic positions such as sales expansion and new marketing channels (Abrahamsson et al., 2003). Where these resources are not perfectly imitable by competitors then they may present a source of competitive advantage to the firm (Barney, 1991). With the long life of warehouse assets, it is thus possible that distribution centres may either form a severe constraint on future flexibility or provide a significant advantage, by facilitating a response to market changes that competitors may find difficult to imitate.

Whilst there are some differences in the precise understanding of the terms agility and flexibility (Abrahamsson et al., 2003), the starting point for this research is the capability to respond to three types of agility that have been described by van Hoek (2001), namely:

- Volume variance, for example caused by seasonality, product life cycles and end consumer demand fluctuations.

- Time variance, for example urgent orders.

- Quantity variance, for example small orders, possibly at item rather than case level. 
These variances represent different logistics challenges and therefore the competencies required to be able to respond to each in a cost effective and timely manner may, in turn, be quite different in nature.

In examining the required competencies, distribution centres may be viewed as part of a wider system i.e. the whole supply chain that forms part of a company's competitive framework (Christopher, 1998). Stevens (1989) recognised the different system levels of supply chains and particularly the inherent need for integration at the external (e.g. with suppliers and customers), internal (e.g. with manufacturing) and functional (e.g. within distribution) levels. This systems approach corresponds to the framework used in analyzing manufacturing flexibility, by, for example, Yussuf et al., (1999) who proposed three levels of agility, namely inter-enterprise, enterprise and resource levels, and by Koste and Malhotra (1999) who examined five tiers ranging from the strategic business unit through to individual resource (e.g. machine) level.

At the distribution function level, distribution centres are frequently part of a network of warehouses serving the customers. The design of these networks involves such decisions as the number, size and location of warehouses, as well as whether they should be owned, leased or outsourced (Lambert et al., 1998). At the level of the individual distribution centres, the necessary resources include labour, space, materials handling equipment, and information systems, as well as the integration of these resources, in terms of processes (Frazelle, 2002a).

These lead to a hierarchical structure for examining distribution competencies as shown in Fig. 1, set out in a similar format to that described for manufacturing flexibilities by Koste and Malhotra (1999).

[Insert Fig. 1 about here] 
Whilst this paper focuses on how distribution centres are designed and operated to provide agility, the wider system responses are also examined as these normally form part of an integrated solution.

\section{Research method}

The research in this paper was based on case studies of six European companies, five in the fast moving consumer goods (FMCG) sector and one in publishing (serving booksellers and academic institutions). Where separate business units had distinctly different supply chains, it was decided that the business unit would be the appropriate unit of analysis. In total, nine business units were examined from the six companies. The focus in all case studies was on outbound distribution.

The first part of the research was undertaken by semi-structured interviews with directors or senior managers examining their view as to the nature of the requirement for agility in their supply chains. The interviews were based on the three categories, plus sub-categories, of agility identified by van Hoek (2001). In addition, the interviewees were given the opportunity to add any other categories of agility that they believed were relevant for their particular operation. The exact requirement of these agility types was explored with the companies, and each sub-category was assessed by the interviewees on a Likert scale of 1 to 5. Metrics were recorded where appropriate, as a record of the degree of agility required (for example, for seasonality, the ratio of peak to average volumes was recorded). This relatively straight-forward method was adopted as the main purpose of the research is to explore the responses to perceived agility requirements, rather than measure the degree of agility itself, for which other possible methods may be appropriate, such as the use of fuzzy logic (Lin et al., 2006). 
The second part of the research was conducted during visits to representative distribution centres within the networks of the business units. The distribution centres included two European Distribution Centres (EDCs), four National Distribution Centres (NDCs) and three Regional Distribution Centres (RDCs), serving parts of the UK. These facilities were within the UK, except for the EDC and an associated NDC, which were located in Poland. The site visits involved undertaking a familiarisation tour of the facility, recording the operational details on a survey form used in previous research and conducting semi-structured interviews with the distribution centre managers (or appropriate senior managers). The semi-structured interviews were based on the types of agility identified during the interviews with supply chain management, having scored 3 or above on the 5-point Likert scale during those interviews. For each of these types of agility, the distribution centre manager was asked how the warehouse was designed and operated to meet the particular requirement. The results were set out within the competency framework outlined in Fig. 1.

A workshop was then held, attended by representatives from five of the six companies. At this workshop each company was given the opportunity to refine its responses in the light of the additional categories of agility identified during the research. In addition, the results were discussed in the form of the hierarchical framework and some initial conclusions were developed.

\section{Research companies}

The nine business units taking part in the research were drawn from the manufacturing, wholesaling, retailing and direct selling sectors, as set out in Table 1.

[Insert Table 1 about here] 


\subsection{Argos Direct: Non-food, non-fashion direct delivery}

Two business units of Argos Direct were included in this research.

$\underline{\text { Argos Direct, Delivery Only (ADDO) }}$ covers items delivered directly to a consumer's home, where two people are required for delivery owing to the weight or nature of the item. The distribution network of ADDO comprises two RDCs; these being located at Stafford and Bedford, with the latter being the focus of this research and comprising $665,000 \mathrm{sq} f t(61,800$ $\mathrm{m}^{2}$ ) in floor area. Whilst seasonality and product life cycles were important issues for this business unit, the accommodation of growth has presented a particular challenge owing to the large cubic measurement of the product lines.

The long lead times resulting from the geographic location of many of the suppliers (e.g. in the Far East) has limited the extent to which inventory holding levels can be tackled at the supply chain and business unit level. The distribution network has thus been expanded by means of additional warehouse area. This has been achieved by renting additional warehouse space and by building an additional RDC (which is managed by a third-party operator). At the distribution centre level, the additional warehouse space has been designed with the nature of the goods and flexibility in mind, comprising mainly wide-aisle adjustable pallet racking and block stacking.

$\underline{\text { Argos Direct, Stocked In (ADSI) }}$ covers items that can be delivered directly to a consumer's home by the driver alone, where these items have typically been ordered by Internet or telephone. 
The ADSI distribution network also comprises two RDCs, located at Tipton and Welwyn Garden City; the latter being the focus of this research and comprising $160,000 \mathrm{sq} f t(14,900$ $\mathrm{m}^{2}$ ). The business unit perceived seasonality and product life cycles as the two key areas of agility required in its supply chain, accentuated by rapid growth in recent years. There are two catalogues per year with about one third of the 8,000 stock-keeping units (SKUs) changing for each catalogue. The peak season throughput is about 3 times above the average level for the year.

Changes of this magnitude required careful planning and co-ordination at all levels. Some examples included the following. At the supply chain level, suppliers were requested to hold stock and deliver in more frequently. The catalogue changes were coordinated at the business unit level, involving merchandising, purchasing and logistics functions. At the distribution network level, changes were made to the RDC delivery areas, whilst at the distribution centre level, there were staff and process changes (such as pickers loading large items directly onto the vehicles at peak periods).

\subsection{Argos Stores: Non-food, non-fashion retailer}

Argos operates 580 stores in the United Kingdom and Eire from a network of 6 Regional Distribution Centres, 3 National Distribution Centres, 2 Direct Import Centres and 2 "Extra" Distribution Centres (for their extended product range at large stores). In total, about 13,500 SKUs are supplied to the stores. The focus of the distribution centre level research was a 340,000 sq ft (31,600 $\left.\mathrm{m}^{2}\right)$ RDC located at Lutterworth in Central England.

The company has experienced rapid growth, with double-digit sales growth in each of the last four years. The distribution network infrastructure has been expanded and restructured to accommodate this growth. Five distribution centres were opened and one closed, adding a net 
1.3 million sq $\mathrm{ft}\left(121,000 \mathrm{~m}^{2}\right)$ to the warehousing capacity, within a three year period. Up until this period, all warehousing was undertaken in-house, but the increased pace of business resulted in the normal 18-30 month time span to plan, build and commission a new building was not sufficiently agile. The decision was therefore taken to use third party logistics contractors where greater speed was required. The third party logistics (3PL) contractors often had warehouses readily available of about the right size in approximately the right location and also had the management and staff resources to react quickly. Thus, during this period, two 3PL warehouses were opened with different contractors, one of 225,000 sq ft $\left(21,000 \mathrm{~m}^{2}\right)$ and the other of $325,000 \mathrm{sq} \mathrm{ft}\left(30,200 \mathrm{~m}^{2}\right)$. Each warehouse was operational within 6-7 months of starting the project planning.

On the other hand, where expansion was part of a long-term strategic plan, it was decided to continue on the in-house route. One example of this was a $650,000 \mathrm{sq} \mathrm{ft}\left(60,400 \mathrm{~m}^{2}\right)$ distribution centre that was opened to act as a national Distribution Centre for small items, an Import Centre (comprising a 90,000 pallet high bay) and a Returns Centre.

\subsection{Avon Cosmetics: manufacturer and direct seller}

The research examined two business units.

Avon Europe distributes goods to the company's national operations from its $86,100 \mathrm{sq} f t$ $\left(8,000 \mathrm{~m}^{2}\right)$ EDC located at its Garwolin manufacturing plant in Poland. The throughput of the EDC has grown rapidly since it became operational in 2000. This growth has partly been accommodated by detailed operational planning software, developed in addition to the Warehouse Management System. This has enabled the EDC to be effective at near capacity levels, particularly at peak seasonal periods. A further challenge has been the change in the 
quantities ordered with more case picking now needed from the largely narrow aisle pallet store. This has been achieved in part by changes in picking process, such as case picking from drop pallets.

Avon Polska serves representatives in the Polish market from its $94,700 \mathrm{sq} \mathrm{ft}\left(8,800 \mathrm{~m}^{2}\right)$ warehouse, again co-located at the Garwolin site. This is largely an item pick operation, utilizing flow racks and conveyors. A major challenge has been the very seasonal and promotional nature of the goods. This has been handled by close internal business unit level co-ordination and by reviewing and changing the Pareto classifications of the goods on a regular monthly basis. The latter involves moving the pick locations of goods so that the new fast-moving lines are located in the prime pick slots, whilst lines that have finished their promotional activity are relocated to slower moving slots.

\subsection{Blueheath: internet wholesaler}

This is a fairly new company, established in 2000 , to serve independent and multiple grocery retailers. The company has experienced rapid growth, aided by its focus on information technology in such areas as inventory control and customer communications. The distribution operation has been set up as a flexible network of companies, with separate contracts in place for warehousing, ambient, chilled and frozen deliveries. The transport operation makes use of spare capacity in existing operations and this aids volume flexibility and growth. The warehousing uses $90,000 \mathrm{sq} \mathrm{ft}\left(8,400 \mathrm{~m}^{2}\right)$ of a $138,000 \mathrm{sq} \mathrm{ft}\left(12,800 \mathrm{~m}^{2}\right)$ shared user third party logistics facility at Tamworth, operated by Gist, and this again provides flexibility for future growth. Up to $50 \%$ temporary staff is used at peak to provide responsiveness to demand variance. 


\subsection{Major retailer}

In order to provide a more agile response to its 1400 stores, this major non-food retailer has worked closely with a 3PL provider to develop a logistics solution. A major challenge has been that of quantity variance, as the operation has moved from pack replenishment to item replenishment for its medium and slow moving lines, which are stocked at a 136,000 sq $\mathrm{ft}\left(12,600 \mathrm{~m}^{2}\right)$ NDC located in the Midlands of the UK. This has enabled store staff to replenish items directly to the shelf in accordance with actual sales and therefore reduced the time spent by staff in the stores. It has also freed up back-of-store stockrooms as selling space, where appropriate. By reducing lead times and simplifying the store replenishment process, on-shelf availability has also been increased.

Providing this "store friendly" capability has involved changes to many aspects of the fulfilment operation. In terms of infrastructure, a high level conveyor has been installed between two nearby warehouses so that the daily despatches can be integrated. The processes have changed substantially so that item picking can be undertaken. At present, goods are stored on pallets and unloaded at the time of replenishing the pick face into totes or cartons ready for item picking. In future, it is planned to receive goods in totes directly from suppliers. The UODs (units of despatch) have been changed so as to provide two sizes of crates for effective transport utilisation. These changes have involved substantial equipment investment in terms of conveyors, stacker lifts and flow racks. The changes affecting the staff involved flexibility of working between warehouses, multi-skilling and 6-day working. 


\subsection{Global drinks company}

The company is a manufacturer of a wide range of alcoholic drinks, with many global brands. This research covered two product groups distributed via the company's $238,000 \mathrm{sq} f t\left(22,100 \mathrm{~m}^{2}\right)$ NDC to both on-trade customers (e.g. brewers and pub groups) and off-trade customers (e.g. national retailers and convenience stores) in the UK.

A key distribution challenge for the company is the handling of the seasonal peak at the end of the year, when about $60 \%$ of the annual volume is despatched within a three-month period. This challenge has been compounded by rapid year-on-year growth, as well as the narrowing of the peak season, as retailers have sought to reduce their own seasonal stockholdings.

The company achieves this high degree of flexibility in the peak season chiefly at the distribution network and distribution centre levels. Particular responses at the network level include sending goods directly from the distilleries to the customers (as the larger volumes make this cost effective and as this relieves pressure on the NDC), renting additional warehouse space, and making stand trailers available for pre-loading. At the distribution centre level, temporary staff are engaged, many of whom work each season on a regular basis and are thus familiar with the operation.

\subsection{Major academic publisher}

The case study focussed on the $118,000 \mathrm{sq} \mathrm{ft}\left(11,000 \mathrm{~m}^{2}\right)$ distribution centre located in the UK serving Europe, Middle East, Africa and Japan. The site acts as a distribution centre for the company's own printed material, as well as a substantial proportion of third party distribution work for other publishers. The chief issues for the distribution centre have been 
the need to accommodate growth (of about $10 \%$ throughput per annum) and handling a reduction in order sizes (e.g. individual books rather than case quantities).

The growth has been accommodated at the business unit level, by increasing the frequency of delivery (i.e. smaller print runs), and, at the distribution network level, by warehouse expansion and the leasing of further storage for bulk stock. At the distribution centre level, space has been freed up by introducing a range of bulk storage locations, so that pallets may move from full pallet locations to half pallet to carton locations, as the pallets are diminished for replenishment. In addition, the increase in titles has been accommodated by reducing the sizes of the pick locations (which has a trade-off with increased replenishment frequency). Information technology, together with improved supplier relationships, has been used to facilitate the increased throughput (e.g. electronic pre-advice and bar code labelling).

The variation in unit size has been handled by having distinct processes in place for pallet, carton, multi-unit and single unit orders. For example, the multi-line orders are batch picked to a second "active pick face" which contains books just required for that day's orders. The locations are thus used for different SKUs and different quantities of SKUs each day. A surplus of locations is provided to accommodate the variations in unit size requirements that occur on a daily basis. Flexibility has been built in to the bar code tracking system so that goods can be tracked through the distribution centre at the pallet, case or unit level, depending on the process stream in question. 


\section{Results}

\subsection{Agility requirements}

For the interviews with supply chain management, the three basic categories identified by van Hoek (2001) formed a meaningful basis for discussing the agility requirements. During these interviews, two additional categories were identified, namely the presentation of the goods (e.g. as display pallets) and the flexible handling of returns. For the aid of clarity during the discussions, it was found useful to separate out information as a distinct category, and to group all requirements related to supplier issues together. This need to react to changes in circumstances relating to suppliers, as well as customers, is also recognised by Stock et al., (1999). A total of seven main categories were therefore used during the interviews, namely: volume, time, quantity, information, presentation, inbound issues and returns. Sub-categories (e.g. seasonality and product life-cycles, as part of the volume variance category) were as noted by van Hoek (2001), together with certain additional sub-categories identified during the interviews. The results are shown in Table 2.

[Insert Table 2 about here]

The results indicate that the greatest requirement for agility in the business units interviewed was in terms of responding to variances in volume (i.e. throughput). Growth and seasonality were the two greatest challenges for these companies, although demand variance, promotions and product life cycles were also rated highly. Rush orders and variations in quantity requirements (e.g. items rather than cases) were important for a number of the business units. Of the inbound issues, unexpected variations in delivery volumes and/or times 
(which were often interrelated) were fairly common challenges, whilst a number of business units also noted flexibility issues with regard to returns.

Having identified the types of agility that were perceived as being important for each business unit, the research then focussed on how the supply chain managers and distribution centre managers actually responded to these requirements. The results for some of the most common variances are described below.

\subsection{Volume variance: growth}

The methods used to accommodate rapid growth centred on distribution network competencies. Both in-house and 3PL solutions were identified. The latter included longterm partnering with 3PL providers who could provide increasing space in shared user warehouses, in the case of smaller operations, and ad-hoc partnering with 3PL providers who could provide ready access to warehouse space, management and staff, in the case of larger operations. However, competencies at different levels were required covering, for example, internal integration (smaller manufacturing runs) and distribution centre design (incorporating extra goods in/out docks for future flexibility). The aggregated findings are shown in Table 3.

[Insert Table 3 about here]

None of the companies were experiencing a fall in volumes, but this would indeed need to be part of the ability to respond to volume variance. 


\subsection{Volume variance: seasonality}

Seasonality was considered to be one of the key areas where agility was needed, with the nine business units having an average seasonal peak of about $100 \%$ above average levels. For one business unit, this seasonal peak represented an increase of $300 \%$. The range of methods by which the distribution centres responded to these peaks is set out in Table 4 .

[Insert Table 4 about here]

The most common methods of responding to seasonal variations were centred on staffing, particularly the use of temporary staff, frequently coupled with the introduction of extra shifts. As well as the extra workload content in the peak season, especially for order picking, there was also pressure on space and renting external warehouses was sometimes used to accommodate this. In addition, a variety of methods were used to adjust the flow of goods either to mitigate the effects on fixed assets or to take advantage of the extra volumes. These included the sequencing of inbound flows in smaller quantities from suppliers and the use of direct deliveries to customers (by-passing the distribution centres). The latter method has the dual advantage of taking advantage of the greater volumes during peak to select a more cost effective routing, whilst at the same time relieving pressure on the distribution centre during this heavy workload period.

\subsection{Volume variance: promotions}

Supplier liaison and cross-functional planning for promotions were only formalised in a couple of the business units and although there were informal processes in the others this 
caused some issues for handling the variations in volumes that occurred. The activities were either outsourced (e.g. for assembling special packs) or the extra volumes were handled by additional staffing (e.g. overtime and weekends). At one site, such measures as the allocation of large picking locations for promotional items and a change in the picking / loading process were adopted.

[Insert Table 5 about here]

\subsection{Volume variance: demand fluctuations}

In terms of demand variance, the responses were focussed on developing competencies at the distribution centre level in order to be able to react whenever they occurred. Most centered around staffing, although there were some solutions in other categories, such as the direct shipment of large orders to customers, by-passing the distribution centre, and the use of additional pick slots that could be allocated to those items in heavy demand. The responses are shown in Table 6.

[Insert Table 6 about here]

The responses relating to the external integration with customers related more to how non-agility was addressed i.e. smoothing flows within the order cycle time (which does not affect customer service within the specified lead times) or rationing deliveries to customers in some way (which does affect service levels). 


\subsection{Time variance}

For time variance (e.g. rush orders), the responses were focussed on process and systems solutions at the distribution centre level. Generally, these orders were accommodated by prioritising them, for example, by the use of real-time warehouse management systems and radio data terminals.

\subsection{Quantity variance}

With regard to quantity variance (e.g. being able to respond to orders for items, cases and pallets), a number of the business units had identifiable processes and workstreams in place for each type of order. Where significant variations were taking place (as in changing from case to item replenishment for stores), this involved competencies at all levels to be able to implement the change. For more minor variances, then the competencies were chiefly at distribution centre level, particularly in terms of processes. The responses are summarised in Table 7.

[Insert Table 7 about here]

\subsection{Inbound variance: volume / time}

On the inbound side, the distribution centres needed to be agile to respond to variances from suppliers whilst minimising the impact on customer service levels. The responses fell into two categories. The first was the resolution of the problem, which was naturally at supply chain level, by co-ordination with the suppliers. The second was at distribution centre 
level in being able to handle these variances if ever they occurred. For example, one business unit had a process to cross-dock back orders automatically, in order to expedite the goods for all outstanding customer orders.

\section{Summary}

A summary of the responses for the main categories of agility identified during the study is set out in Table 8 .

[Insert Table 8 about here]

These results indicate that the business units used competencies at a combination of levels, particularly where there was prior knowledge that some degree of variance was likely to occur, for example in terms of promotions and seasonality. Growth was largely handled internally, with large scale-growth being enabled at the business unit and distribution network level, although moderate growth could be addressed at the distribution centre level. Similarly, quantity variance involved multi-levels where it affected the whole supply chain, but was handled at the distribution centre level otherwise. Rush orders from customers and late / incomplete receipts from suppliers were accommodated at the distribution centre level, although, in the case of the latter, resolution of the issue obviously occurred in co-ordination with the suppliers.

The detailed breakdown of the distribution centre level responses is set out in Table 9. This shows the combinations of competencies used at that level to respond to different types of variance. For example, growth was largely tackled by equipment design, time variance by 
process / systems solutions, whilst seasonal and demand variances were handled chiefly by staffing policies.

[Insert Table 9 about here]

In the workshop discussion, it was agreed that agility could best be handled where variances are tackled at all four levels. The supply chain and business unit levels are important for planning, smoothing throughputs, resolving issues and restructuring the supply network, whilst the distribution network and distribution centre levels need to be designed to handle the true variances that remain. Practical difficulties were acknowledged that needed to be overcome to achieve the type of integration needed. Particular examples cited include:

- The commercial sensitivity of promotions and thus the lack of prior knowledge even within the organisation.

- The precision of marketing information (e.g. forthcoming promotional activity at SKU, rather than generic product line, level).

- The writing-off and disposal of old inventory to make way for new product lines.

- The alignment of performance metrics and incentives to business goals (e.g. the use of unit cost manufacturing metrics).

- The organisational structure and responsibilities (e.g. the role of supply chain management, as well as the particular role of distribution centre management in decision making).

A pre-requisite to the capability to respond to volatile markets is thus the organisational and information-sharing competencies that form the basis of much of the supply chain 
management concept. These need to be present at the levels of external, internal and functional integration as noted by Stevens (1989). The framework developed in this paper can then be used as a basis for developing the capabilities to respond to the different types of agility that are required by the market.

\section{Conclusions}

Creating a customer focussed, responsive capability requires an organisation-wide orientation towards customer retention, supported by an appropriate structure and information systems (Day, 2003). The importance of such a demand-side orientation in supply chain strategy, and its link to agility, is supported by research undertaken by Morash (2001). However, it should be recognised that this orientation will only offer sustained competitive advantage if it is a dynamic capability capable of renewing competencies so as to achieve continual alignment with the changing business environment (Teece et al., 1997).

The framework outlined above offers a tool for companies to review their responsiveness to the market from the viewpoint of the actual operation at distribution centre level. It does however need to be reviewed constantly to ensure that the competencies are in place to respond to the types of agility that are likely to be faced. There appears not to be a "one size fits all" solution for all agility types. Different combinations of competencies are needed to address each type of agility, and this supports Zhang et al., (2002). However, many of the competencies are common across a number of agility types. For example, flexible staffing arrangements were used to provide agile responses to seasonality, promotions, product life cycle changes, demand variances, as well as to inbound variances. Some of the main competencies identified by the case studies were the ability to: 
- optimise the supply chain in conjunction with suppliers and customers;

- plan and make trade-off decisions across company functions;

- $\quad$ flex the space used within shared-user 3PL warehouses (for smaller operations);

- access additional rented warehousing space quickly;

- plan and have new warehouses operational rapidly (either own warehouses or through a 3PL);

- route flows through the network in line with changing circumstances;

- design buildings and equipment for growth and flexibility;

- $\quad$ adopt flexible staffing arrangements (for own and temporary staff);

- put processes in place to address potential variances;

- $\quad$ support these processes with appropriate information systems.

These competencies occur at all levels from external integration (e.g. with suppliers and customers) through to the distribution centre level and this supports the view by Mason-Jones and Towill (1999, p 62) that systems thinking is "the ideal way to approach the problem of designing agile supply chains".

The framework is intended to provide a useful tool to practitioners for assessing the types of agile capabilities required and the competencies that need to be put in place to respond to these eventualities. It can act as an initial check-list to ensure that potential competencies at each level have been considered. The relative implication of each option in terms of range, mobility, uniformity and cost (Upton, 1994) can then be assessed by practitioners. For example, some companies are addressing agility in terms of cost adaptability, by reducing fixed costs (Katayama and Bennett, 1999), and this framework presents a first step for identifying the possible options to be examined. Such implications provide an area for further research into this subject. 
This case study research has been based on nine business units and has concentrated on outward distribution in the fast-moving consumer goods sector. Its applicability to other parts of the supply chain and to other sectors thus needs to be validated, as well as a more detailed exploration of potential competencies at each level. In particular, further research is required to identify the common competencies that are required to enable responsiveness across a number of agility types and thus for distribution centres to be agile in the true sense of the word.

In the case studies researched, most of the distribution centres were dedicated to the particular companies involved, especially for the larger operations. These distribution centres represent expensive fixed assets (however they are financed or operated) and are pivotal to the provision of high customer service levels. As noted by Frazelle (2002b), distribution centres are critical to the success or failure of many companies. It is thus imperative that distribution centres are fully integrated into the planning and operations of companies' supply chains, and that they are designed and operated in order to be able to meet the responsiveness to the market that may be required, in spite of the fixed asset nature of major distribution operations. In fact, this fixed asset nature can make distribution infrastructures difficult to imitate by competitors and thus provide a source of competitive advantage for a company (as per Barney, 1991). This is a major challenge for practitioners in the field. 


\section{References}

Abrahamsson, M., N. Aldin and F. Stahre, 2003, Logistics Platforms for Improved Strategic Flexibility, International Journal of Logistics: Research and Applications 6 (3), 85-106.

Aitken, J., M. Christopher and D. Towill, 2002, Understanding, Implementing and Exploiting Agility and Leanness, International Journal of Logistics: Research and Applications 5 (1), 59-74.

Baker, P., 2004, Aligning Distribution Centre Operations to Supply Chain Strategy, International Journal of Logistics Management 15 (1), 111-123.

Barney, J., 1991, Firm Resources and Sustained Competitive Advantage, Journal of Management 17 (1), 99-120.

Childerhouse, P. and D. Towill, 2000, Engineering Supply Chains to Match Customer Requirements, Logistics Information Management 13 (6), 337-345.

Christopher, M., 1998, Logistics and Supply Chain Management, $2^{\text {nd }}$ edition (Pearson, Harlow).

Christopher, M., 2000, The Agile Supply Chain: Competing in Volatile Markets, Industrial Marketing Management 29, 37-44.

Christopher, M. and D. Towill, 2002, Developing Market Specific Supply Chain Strategies, International Journal of Logistics Management 13 (1), 1-14.

Day, G. S., 2003, Creating a Superior Customer-Relating Capability, MIT Sloan Management Review, Spring, 77-82.

Frazelle, E. H., 2002a, World-Class Warehousing and Material Handling (McGraw-Hill, New York). 
Frazelle, E. H., 2002b, Supply Chain Strategy: The Logistics of Supply Chain Management (McGraw-Hill, New York).

Harrison, A. and R. van Hoek, 2005, Logistics Management and Strategy, $2^{\text {nd }}$ edition (Pearson, Harlow).

Herer, Y.T., M. Tzur and E. Yucesan, 2002, Transshipments: An Emerging Inventory Recourse to Achieve Supply Chain Leagility, International Journal of Production Economics 80, 201-212.

Katayama, H and D. Bennett, 1999, Agility, Adaptability and Leanness: A Comparison of Concepts and a Study of Practice, International Journal of Production Economics 6061, 43-51.

Koste, L. L. and M.K. Malhotra, 1999, A Theoretical Framework for Analyzing the Dimensions of Manufacturing Flexibility, Journal of Operations Management 18, 7593.

Lambert, D. M., J.R. Stock and L.M. Ellram, 1998, Fundamentals of Logistics Management (McGraw-Hill, Singapore).

Lin, C-H., H. Chiu and P-Y. Chu, 2006, Agility Index in the Supply Chain, International Journal of Production Economics 100, 285-299.

Maltz, A and N. DeHoratius, 2004, Warehousing: The Evolution Continues (Warehousing Education and Research Council, Oak Brook).

Marvick, D and J. White, 1998, Distribution Operations: Managing Distribution Facilities for Strategic Advantage”, in Gattorna J Strategic Supply Chain Alignment (Gower, Aldershot).

Mason-Jones, R., B. Naylor and D.R. Towill, 2000, Engineering the Leagile Supply Chain, International Journal of Agile Management Systems 2 (1), 54-61. 
Mason-Jones, R and D.R. Towill, 1999, Total Cycle Time Compression and the Agile Supply Chain, International Journal of Production Economics 62, 61-73.

Morash, E. A., 2001, Supply Chain Strategies, Capabilities, and Performance, Transportation Journal 41 (1), 37-54.

Naylor, J. B., M. M. Naim and D. Berry, 1999, Leagility: Integrating the Lean and Agile Manufacturing Paradigms in the Total Supply Chain, International Journal of Production Economics 62, 107-118.

Office for National Statistics, 2005, Economic Trends, www.statistics.gov.uk.

Pfohl, H-C., W.A. Zollner and N. Weber, 1992, Economies of scale in customer warehouses: theoretical and empirical analysis, Journal of Business Logistics 13 (1), 95-124.

Sharifi, H and Z. Zhang, 1999, A Methodology for Achieving Agility in Manufacturing Organisations: An Introduction, International Journal of Production Economics 62, $7-22$.

Stalk, G., P. Evans and L.E. Shulman, 1992, Competing on Capabilities: the New Rules of Corporate Strategy, Harvard Business Review, March-April, 57-69.

Stevens, G. C., 1989, Integrating the Supply Chain, International Journal of Physical Distribution and Materials Management 19 (8), 3-8.

Stock, G. N., N.P. Greis and J.D. Kasarda, 1999, Logistics, Strategy and Structure, International Journal of Physical Distribution \& Logistics 29 (4), 37-52.

Stratton, R. and R.D.H. Warburton, 2003, The Strategic Integration of Agile and Lean Supply, International Journal of Production Economics 85, 183-198.

Teece, D. J., G. Pisano and A. Shuen, 1997, Dynamic Capabilities and Strategic Management, Strategic Management Journal 18 (7), 509-533. 
Upton, D.M., 1994, The Management of Manufacturing Capability, California Management Review, Winter, 72-89.

Van Hoek, R. I., 2001, Epilogue: Moving Forward with Agility, International Journal of Physical Distribution \& Logistics Management 31 (4), 290-300.

Van Hoek, R. I., A. Harrison and M. Christopher, 2001, Measuring Agile Capabilities in the Supply Chain, International Journal of Operations \& Production Management 21 $(1 / 2), 126-147$.

Yusuf, Y.Y., M. Sarhadi and A. Gunasekaran, 1999, Agile Manufacturing: The Drivers, Concepts and Attributes, International Journal of Production Economics 62, 33-43.

Zhang, Q., M.A.Vonderembse and J-S Lim, 2002, Value Chain Flexibility: a Dichotomy of Competence and Capability, International Journal of Production Research 40 (3), $561-583$. 
Fig. 1

Hierarchical framework for examining distribution centre competencies

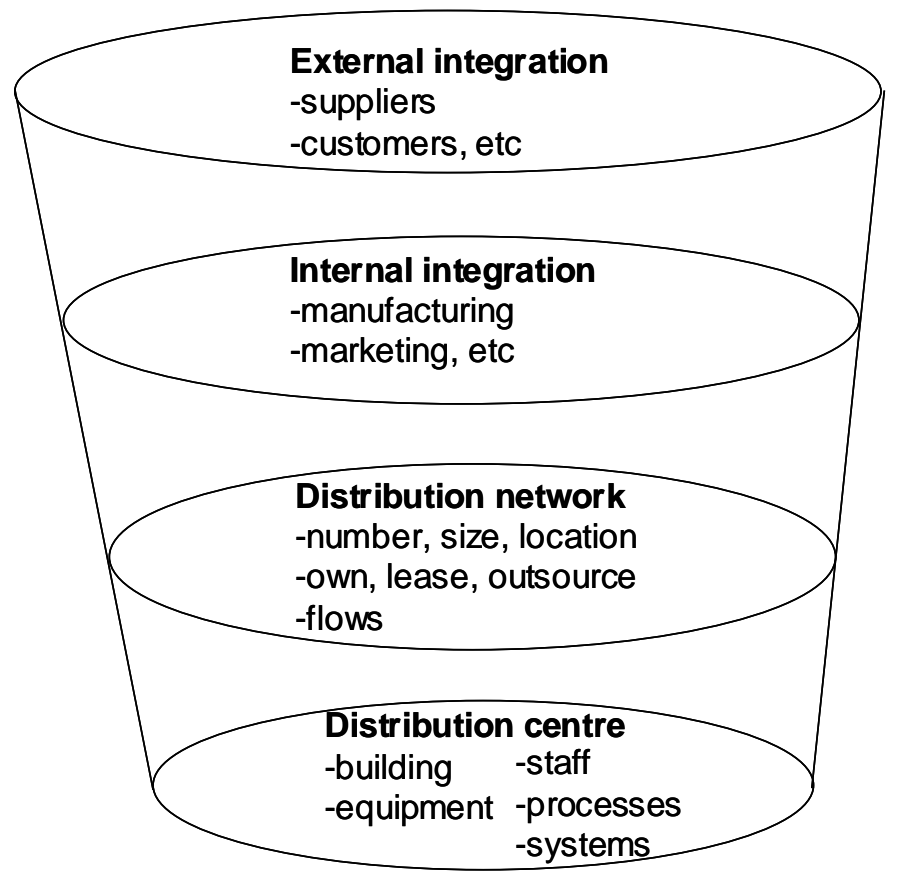

Supply chain level

Business unit level

Physical distribution level

Warehouse level 
Table 1

Business units taking part in the research by sector

\begin{tabular}{|c|c|c|c|c|c|c|c|c|c|}
\hline & $\begin{array}{c}\text { Argos } \\
\text { Direct } \\
\text { (ADDO) } \\
\end{array}$ & $\begin{array}{c}\text { Argos } \\
\text { Direct } \\
\text { (ADSI) }\end{array}$ & $\begin{array}{l}\text { Argos } \\
\text { Stores }\end{array}$ & $\begin{array}{c}\text { Avon } \\
\text { Europe }\end{array}$ & $\begin{array}{c}\text { Avon } \\
\text { Poland }\end{array}$ & $\begin{array}{l}\text { Blue- } \\
\text { heath }\end{array}$ & $\begin{array}{l}\text { Major } \\
\text { retailer }\end{array}$ & $\begin{array}{c}\text { Global } \\
\text { drinks } \\
\text { company }\end{array}$ & $\begin{array}{c}\text { Major } \\
\text { academic } \\
\text { publisher }\end{array}$ \\
\hline Manufacturer & & & & $*$ & & & $*$ & $*$ & $*$ \\
\hline Wholesaler & & & & & & $*$ & & & $*$ \\
\hline Retailer & & & $*$ & & & & $*$ & & \\
\hline Direct seller & $*$ & $*$ & & $*$ & $*$ & & & & $*$ \\
\hline
\end{tabular}


Table 2

Results of supply chain management interviews

\begin{tabular}{|c|c|c|c|c|c|c|c|c|c|c|}
\hline & $\begin{array}{l}\text { Argos } \\
\text { Direct } \\
\text { ADDO } \\
\end{array}$ & $\begin{array}{l}\text { Argos } \\
\text { Direct } \\
\text { ADSI } \\
\end{array}$ & $\begin{array}{l}\text { Argos } \\
\text { Stores }\end{array}$ & $\begin{array}{c}\text { Avon } \\
\text { Europe }\end{array}$ & $\begin{array}{c}\text { Avon } \\
\text { Poland }\end{array}$ & $\begin{array}{l}\text { Blue- } \\
\text { heath }\end{array}$ & $\begin{array}{l}\text { Major } \\
\text { retailer }\end{array}$ & $\begin{array}{c}\text { Global } \\
\text { drinks } \\
\text { co. } \\
\end{array}$ & $\begin{array}{c}\text { Major } \\
\text { publish } \\
\text {-er }\end{array}$ & Average \\
\hline \multicolumn{11}{|l|}{ Volume } \\
\hline Growth & 5 & 2 & 5 & 4 & 5 & 5 & 3 & 5 & 5 & 4.3 \\
\hline Seasonality & 3 & 5 & 5 & 5 & 4 & 4 & 5 & 5 & 3 & 4.3 \\
\hline Promotions & 2 & 4 & 3 & 3 & 3 & 4 & 3 & 4 & 1 & 3.0 \\
\hline Life cycles & 5 & 5 & 3 & 2 & 1 & 3 & 3 & 3 & 2 & 3.0 \\
\hline $\begin{array}{l}\text { Demand } \\
\text { variance }\end{array}$ & 4 & 4 & 2 & 5 & 3 & 4 & 4 & 3 & 4 & 3.7 \\
\hline \multicolumn{11}{|l|}{ Time } \\
\hline Rush orders & 3 & 4 & 1 & 5 & 2 & 1 & 4 & 3 & 1 & 2.7 \\
\hline \multicolumn{11}{|l|}{ Quantities } \\
\hline $\begin{array}{l}\text { Units vs cases } \\
\text { vs pallets }\end{array}$ & 1 & 1 & 1 & 5 & 1 & 2 & 5 & 1 & 4 & 2.3 \\
\hline \multicolumn{11}{|l|}{ Presentation } \\
\hline Outbound & 2 & 1 & 1 & 2 & 2 & 1 & 4 & 3 & 1 & 1.9 \\
\hline \multicolumn{11}{|l|}{ Information } \\
\hline $\begin{array}{l}\text { Customised } \\
\text { information }\end{array}$ & 1 & 4 & 1 & 2 & 1 & 5 & 1 & 1 & 1 & 1.9 \\
\hline \multicolumn{11}{|l|}{ Inbound } \\
\hline Volume/time & 1 & 1 & 3 & 1 & 1 & 4 & 2 & 4 & 5 & 2.4 \\
\hline $\begin{array}{l}\text { Units vs cases } \\
\text { vs pallets }\end{array}$ & 5 & 1 & 1 & 1 & 1 & 1 & 1 & 1 & 4 & 1.8 \\
\hline Presentation & 1 & 1 & 1 & 1 & 1 & 2 & 5 & 1 & 2 & 1.7 \\
\hline Information & 3 & 1 & 1 & 1 & 1 & 1 & 1 & 1 & 1 & 1.2 \\
\hline \multicolumn{11}{|l|}{ Returns } \\
\hline $\begin{array}{l}\text { Returned } \\
\text { goods }\end{array}$ & 3 & 4 & 3 & 1 & 1 & 1 & 3 & 2 & 3 & 2.3 \\
\hline
\end{tabular}

Key: Results show the degree of agility perceived as being needed on a Likert scale of 1 to 5:

$5=$ "very high", 4 = "high", 3 = "average", 2 = "low", 1 = "very low or none". 
Table 3

Methods used to respond to growth

\begin{tabular}{|c|c|c|}
\hline Competency & Method & $\begin{array}{c}\text { Number of } \\
\text { business units }\end{array}$ \\
\hline \multicolumn{3}{|l|}{ External integration } \\
\hline - suppliers & - & 0 \\
\hline \multicolumn{3}{|l|}{ Internal integration } \\
\hline $\begin{array}{l}\text { - manufacturing, } \\
\text { marketing, etc }\end{array}$ & $\begin{array}{l}\text { Smaller manufacturing runs } \\
\text { Annual cross functional planning }\end{array}$ & $\begin{array}{l}1 \\
1\end{array}$ \\
\hline \multicolumn{3}{|c|}{ Distribution network } \\
\hline $\begin{array}{l}\text { - number / size of } \\
\text { warehouses }\end{array}$ & $\begin{array}{l}\text { Additional warehouse space rented } \\
\text { Expanded use of shared-user } \\
\text { warehouse } \\
\text { Excess space commitment in shared- } \\
\text { user warehouse } \\
\text { Use of 3PLs to obtain warehouses } \\
\text { quickly } \\
\text { Revised role of warehouses } \\
\text { Use of other own warehouses } \\
\text { Warehouse expansion } \\
\text { More own warehouses }\end{array}$ & $\begin{array}{l}1 \\
1 \\
1 \\
1 \\
1\end{array}$ \\
\hline - flows & $\begin{array}{l}\text { Reduced intake from import } \\
\text { warehouses } \\
\text { Use of drop trailers } \\
\end{array}$ & $\begin{array}{l}1 \\
1\end{array}$ \\
\hline Distribution centre & & \\
\hline - building & Excess docks & 1 \\
\hline - equipment & $\begin{array}{l}\text { Smaller pick bins } \\
\text { Flexible storage - block stack, wide } \\
\text { aisle pallet racking } \\
\text { More wide aisle for SKU growth }\end{array}$ & $\begin{array}{l}1 \\
1\end{array}$ \\
\hline - staff & Additional shifts & 1 \\
\hline - process & - & 0 \\
\hline - systems & Use of information technology & 1 \\
\hline
\end{tabular}


Table 4

Methods used to respond to seasonal peaks

\begin{tabular}{lll}
\hline \multicolumn{1}{c}{ Competency } & \multicolumn{1}{c}{ Method } & $\begin{array}{c}\text { Number of } \\
\text { business units }\end{array}$ \\
\hline External integration & & 1 \\
\hline - suppliers & Local suppliers hold stock & 1 \\
\hline Internal integration & Sequence inbound in smaller quantities & 2 \\
\hline - manufacturing, & Cross functional pre-planning & 1 \\
marketing, etc & & 2 \\
\hline - transport & Use of stand trailers & \\
\hline Distribution network & & 1 \\
\hline - number / size of & Rent additional warehouse space & 1 \\
warehouses & & 1 \\
\hline - flows & Direct deliveries by-passing DC & \\
& Modify delivery areas of RDCs & 1 \\
\hline Distribution centre & Smaller replenishments from NDC to RDCs & 6 \\
\hline - equipment & & 4 \\
\hline - staff & Hire extra materials handling equipment & 3 \\
& Temporary staff & 1 \\
\hline - process & Extra shifts & 2 \\
\hline - systems & Overtime / weekends & 1 \\
\hline
\end{tabular}


Table 5

Methods used to respond to promotions

\begin{tabular}{llc}
\hline \multicolumn{1}{c}{ Competency } & \multicolumn{1}{c}{ Method } & $\begin{array}{c}\text { Number of } \\
\text { business } \\
\text { units }\end{array}$ \\
\hline External integration & \multicolumn{1}{c}{ Supplier liaison } & 1 \\
\hline - suppliers & \multicolumn{1}{c}{ Cross functional pre-planning } \\
\hline Internal integration & & 2 \\
\hline - manufacturing, & & 1 \\
\hline marketing, etc & Outsource off-site & 0 \\
\hline - nistribution network & & 0 \\
warehouses & & 1 \\
\hline - flows & & 1 \\
\hline Distribution centre & - & 1 \\
\hline - building & Large promotional pick locations & 1 \\
\hline - equipment & Weekends & 1 \\
\hline - staff & Extra shifts & 0 \\
\hline - process & Outsource on-site & \\
\hline - systems & Pickers also load high-cube items & \\
\hline
\end{tabular}


Table 6

Methods used to respond to demand variance

\begin{tabular}{lll}
\hline \multicolumn{1}{c}{ Competency } & \multicolumn{1}{c}{ Method } & $\begin{array}{c}\text { Number of } \\
\text { business units }\end{array}$ \\
\hline External integration & & \\
\hline - suppliers & & \\
- customers & $\begin{array}{l}\text { Smooth output within order cycle time } \\
\text { Prioritise orders }\end{array}$ & 2 \\
\hline Internal integration & & 0 \\
\hline - manufacturing, & - & \\
marketing, etc & & 0 \\
\hline Distribution network & & 1 \\
\hline - number / size of & - & 0 \\
warehouses & & 1 \\
\hline - flows & Drop ship large orders by-passing DC \\
\hline Distribution centre & & 4 \\
\hline - building & - & 3 \\
\hline - equipment & "Day" pick slots & 3 \\
\hline - staff & Multi-skilled staff & 2 \\
& Temporary staff & 1 \\
& Weekends & 1 \\
& Overtime & 1 \\
\hline - process & Staffing above average & 1 \\
\hline - systems & Flexible hours & 1 \\
\hline
\end{tabular}


Table 7

Methods used to respond to quantity variance

\begin{tabular}{|c|c|c|}
\hline Competency & Method & $\begin{array}{c}\text { Number of } \\
\text { business units }\end{array}$ \\
\hline \multicolumn{3}{|c|}{ External integration } \\
\hline - suppliers & Unit load change & 1 \\
\hline - customers & Unit load change & 1 \\
\hline \multicolumn{3}{|l|}{ Internal integration } \\
\hline $\begin{array}{l}\text { - manufacturing, } \\
\text { marketing, etc }\end{array}$ & Change to store operations & 1 \\
\hline \multicolumn{3}{|c|}{ Distribution network } \\
\hline $\begin{array}{l}\text { - number / size of } \\
\text { warehouses }\end{array}$ & - & 0 \\
\hline - flows & Extend working week & 1 \\
\hline \multicolumn{3}{|l|}{ Distribution centre } \\
\hline - building & - & 0 \\
\hline \multirow[t]{2}{*}{ - equipment } & Conveyors and flow racks & 1 \\
\hline & Surplus active locations & 1 \\
\hline - staff & - & \\
\hline \multirow[t]{6}{*}{ - process } & $\begin{array}{l}\text { Unit, case and pallet processes / } \\
\text { workstreams }\end{array}$ & 2 \\
\hline & Pick from bulk & 1 \\
\hline & Drop pallet & 1 \\
\hline & Extend working week & 1 \\
\hline & Pick every store every day & 1 \\
\hline & Reduce lead time & 1 \\
\hline \multirow[t]{2}{*}{ - systems } & System changes & 1 \\
\hline & IT - unit bar code & 1 \\
\hline
\end{tabular}


Table 8

Summary of responses by agility type and competency level (number of business units)

\begin{tabular}{llllllll}
\hline & Agility type & & & & \\
\hline $\begin{array}{l}\text { Competency } \\
\text { level }\end{array}$ & Growth & Seasonal & $\begin{array}{c}\text { Promo- } \\
\text { tions }\end{array}$ & $\begin{array}{c}\text { Demand } \\
\text { variance }\end{array}$ & $\begin{array}{c}\text { Time } \\
\text { variance }\end{array}$ & $\begin{array}{c}\text { Quantity } \\
\text { variance }\end{array}$ & $\begin{array}{c}\text { Inbound } \\
\text { volume } \\
\text { time } \\
\text { variance }\end{array}$ \\
\hline $\begin{array}{l}\text { External } \\
\text { integration }\end{array}$ & 0 & 3 & 1 & 3 & 0 & 1 & 2 \\
\hline $\begin{array}{l}\text { Internal } \\
\text { integration }\end{array}$ & 3 & 3 & 2 & 0 & 1 & 1 & 0 \\
\hline $\begin{array}{l}\text { Distribution } \\
\text { network }\end{array}$ & 6 & 3 & 1 & 1 & 0 & 1 & 0 \\
\hline $\begin{array}{l}\text { Distribution } \\
\text { centre }\end{array}$ & 4 & 9 & 2 & 6 & 3 & 4 & 3 \\
\hline
\end{tabular}


Table 9

Summary of responses by agility type and DC competency (number of business units)

\begin{tabular}{llllllll}
\hline & \multicolumn{3}{l}{ Agility type } & & & & \\
\hline D C competency & Growth & Seasonal & $\begin{array}{l}\text { Promo- } \\
\text { tions }\end{array}$ & $\begin{array}{l}\text { Demand } \\
\text { variance }\end{array}$ & $\begin{array}{l}\text { Time } \\
\text { variance }\end{array}$ & $\begin{array}{l}\text { Quantity } \\
\text { variance }\end{array}$ & $\begin{array}{l}\text { Inbound } \\
\text { volume } \\
\text { time } \\
\text { variance }\end{array}$ \\
\hline - building & 1 & 0 & 0 & 0 & 0 & 0 & 1 \\
\hline - equipment & 3 & 1 & 1 & 1 & 0 & 2 & 0 \\
\hline - staff & 1 & 8 & 2 & 5 & 0 & 1 & 0 \\
\hline - process & 0 & 3 & 2 & 1 & 2 & 4 & 1 \\
\hline - systems & 1 & 2 & 0 & 1 & 2 & 2 & 1 \\
\hline
\end{tabular}

